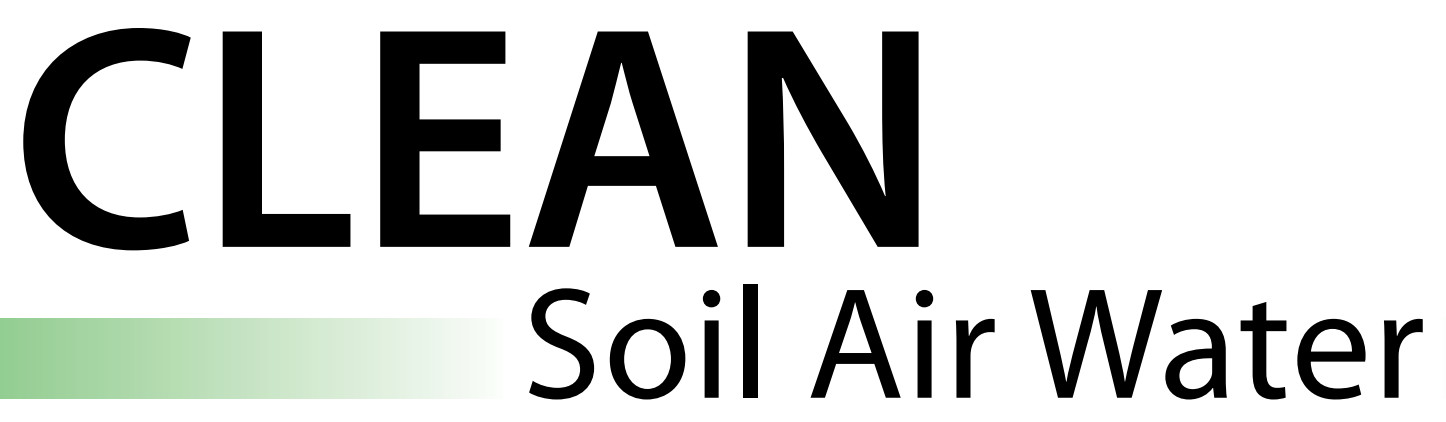

Renewables

Sustainability

Environmental Monitoring

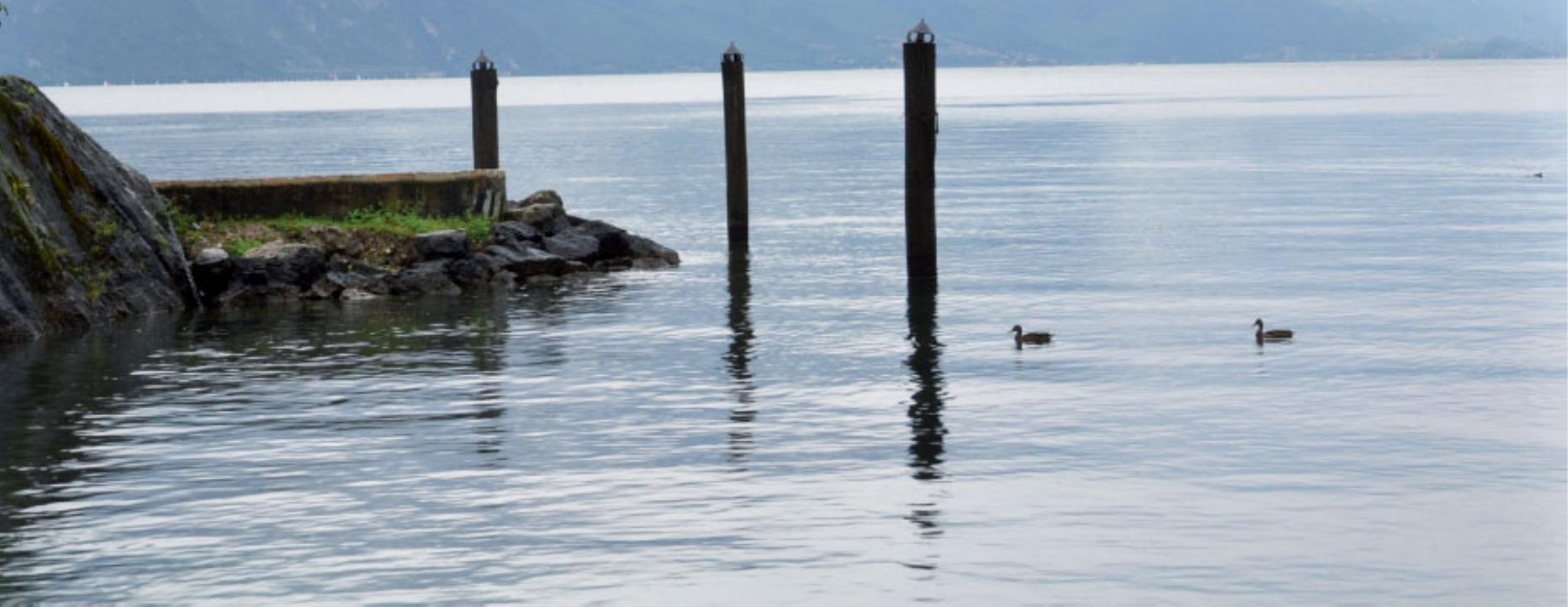




\author{
Wenzhong Tang ${ }^{1, *, *}$ \\ Baoqing Shan ${ }^{1, \#}$ \\ Jingguo Cui ${ }^{2}$ \\ Yu Zhao' \\ Wenqiang Zhang ${ }^{1}$ \\ ${ }^{1}$ State Key Laboratory on \\ Environmental Aquatic Chemistry, \\ Research Center for Eco- \\ Environmental Sciences, Chinese \\ Academy of Sciences, Beijing, P. R. \\ China \\ ${ }^{2}$ CECEP L\&T Environmental \\ Technology Co., Ltd., Beijing, P. R. \\ China
}

\section{Research Article \\ Effects of Nitrogen Pollution on Periphyton Distribution, Elemental Composition and Assemblage Shifts in River Ecosystems}

Ecological stoichiometry (ES) can provide a good insight and predictive power for environmental research. For some years, it has been suggested that ES should be used in river ecosystem studies. This study applied this method to a river system of Hai River Basin (HRB), to identify which pollutants affect periphyton distribution and how pollutants affect periphyton stoichiometry. In rivers with different levels of nitrogen (N) pollution, periphyton could be classified into three groups based on typologies as follows: attached diatoms $(\mathrm{AD})$, filamentous algae $(\mathrm{FA})$, and filamentous algae with epiphyte (FE). AD represented clean ambient water, FE indicated slight pollution, and FA showed that water had been contaminated by $\mathrm{N}$. Ammonium nitrogen $\left(\mathrm{NH}_{4}{ }^{+}-\mathrm{N}\right)$ was the main factor of periphyton distribution and assemblage shifts. The carbon/ $\mathrm{N}$ ratio differed significantly between the groups, and values were 14 for $\mathrm{AD}, 12$ for $\mathrm{FE}$, and ten for FA. The N/phosphorus (P) ratios for $\mathrm{AD}, \mathrm{FE}$, and FA were 47, 24, and 19, respectively. $\mathrm{NH}_{4}{ }^{+}-\mathrm{N}$ and total $\mathrm{P}$ (TP) controlled the $\mathrm{N} / \mathrm{P}$ ratio of $\mathrm{AD}, \mathrm{NO}_{\mathrm{x}}{ }^{-} \mathrm{N}$ (nitrite and nitratenitrogen) controlled the N/P ratio of FE and TP controlled the N/P ratio of FA. Based on the changes observed in periphyton assemblages in the HRB, managing and controlling $\mathrm{N}$ pollution in freshwater, especially from $\mathrm{NH}_{4}{ }^{+} \mathrm{N}$, should be prioritized.

Keywords: Ecological stoichiometry; Fluvial ecosystems; Freshwater management strategies; Nutrients; Photoautotropic communities

Received: January 16, 2014; revised: April 18, 2014; accepted: May 24, 2014

DOI: $10.1002 /$ clen.201300927

Additional supporting information may be found in the online version of this article at the publishor's web-site.

\section{Introduction}

From an environmental view, nutrients including nitrogen $(\mathrm{N})$, phosphorus (P), and silica (Si) that harm an ecosystem are defined as pollution $[1,2]$. While $\mathrm{N}$ or $\mathrm{P}$, as a rather reactive tracer, is mainly representative for shallow and surface flow pathways and anthropogenic sources, $\mathrm{Si}$, as a more conservative tracer, represents long-term background sources of the lithological substrata [3, 4]. Therefore, unlike Si, N, and P pollution usually appear in the river ecosystems, and have a significant impact on river aquatic organisms, especially periphyton [5]. Periphyton is a significant component of fluvial ecosystems [5, 6] and plays an important role in fluvial food web regimes [7-9]. Many researchers have used periphyton as an indicator of environmental change $[10,11]$ or of freshwater ecosystem restoration in rivers, lakes, and wetlands $[12,13]$.

Correspondence: Professor B. Q. Shan, State Key Laboratory on Environmental Aquatic Chemistry, Research Center for EcoEnvironmental Sciences, Chinese Academy of Sciences, Beijing 100085, P. R. China

E-mail: bqshan@rcees.ac.cn

Abbreviations: AD, attached diatoms; CRW, Chaobai River watershed; ES, ecological stoichiometry; FA, filamentous algae; FE, filamentous algae with epiphyte; $\mathrm{HRB}$, Hai River basin; $\mathrm{NH}_{4}{ }^{+} \mathrm{N}$, ammonium nitrogen; $\mathrm{NO}_{2}{ }^{-}-\mathrm{N}$, nitrite-nitrogen; $\mathrm{NO}_{3}{ }^{-} \mathrm{N}$, nitrate-nitrogen; TN, total N; TP, total P
Ecological stoichiometry (ES) is a new branch of ecology for studying the mechanism and balance of nutrients and energy in different life systems [14-16]. As a novel method, ES offers a multivariate approach at multiple dimensions using elemental ratios and can provide additional insights and predictive power for environmental research $[17,18]$. Application of ES has shown that pollution can result in changes in the elemental content of periphyton, because photoautotrophic organisms are generally believed to exhibit great plasticity in their elemental composition, and generally lack homeostasis [17]. Early in 1978, Rhee found that the N/P ratio of Scenedesmus exactly matched the $\mathrm{N} / \mathrm{P}$ ratio of its environment [19]. Experimental simulation further showed that the percentages of $\mathrm{N}$ and $\mathrm{P}$ in periphyton increased as the $\mathrm{N}$ and $\mathrm{P}$ concentrations of river water increased, and the periphyton $\mathrm{N} / \mathrm{P}$ ratio tracked the water $\mathrm{N} / \mathrm{P}$ ratio [20]. Previous studies have demonstrated that we could use periphyton to study the environmental impacts of $\mathrm{N}$ and $\mathrm{P}$ pollution in rivers by $\mathrm{ES}$ method.

In recent years, there have been suggestions that ES could be used in studies of ecological processes in benthic ecosystems [21].

*Additional correspondence: Dr. W. Z. Tang, e-mail: wztang@rcees.ac.cn "Wenzhong Tang and Baoqing Shan contributed equally to this work. 
Periphyton stoichiometry might be a good indicator for monitoring and predicting $\mathrm{N}$ or $\mathrm{P}$ pollution, especially in shallow rivers. As such, we firstly used the ES method to analyze changes in the elemental content of periphyton resulting from $\mathrm{N}$ and $\mathrm{P}$ pollution in the Hai River Basin (HRB). The aims of the present study were to (1) identify the main pollutants affecting the periphyton distribution, (2) investigate how $\mathrm{N}$ pollution affected periphyton stoichiometry, and (3) provide advice for environmental restoration in the HRB.

\section{Materials and methods}

\subsection{Study area}

The HRB, located in northern China, is one of several major basins under the management of the Ministry of Water Resources. The HRB covers an area of $318000 \mathrm{~km}^{2}$, and its climate is temperate continental monsoon. The mean annual precipitation is $527 \mathrm{~mm}$. Heavy industrial development and rapid urbanization have caused significant pollution of freshwater in this region, especially $\mathrm{N}$ pollution. There is high demand for water resources and the deterioration of water quality has exacerbated the shortage of water resources, and many rivers in the HRB have also shrunk into shallow streams. This has resulted in periphyton (mainly benthic algae) becoming the major constituent, especially in the upland area. The HRB has attracted much attention from the Chinese government and has become one of the most important basins in the National 11th and 12th Five-year Plan for Water Pollution Control.

The Chaobai River watershed (CRW), one of the most important watersheds in the HRB (Fig. 1), is a significant source of drinking water for Beijing. The Miyun Reservoir, located $100 \mathrm{~km}$ northeast of the capital, is at the confluence of the Chao and Bai rivers. Drought and water overuse have diminished some parts of the downstream flow of the Chao River in recent years, while the Bai River has been transformed into a subalpine shallow stream with a gravel/cobble riverbed. Cornfields lie on either side of the Bai River and are the source of agricultural non-point pollution. We selected the Bai and

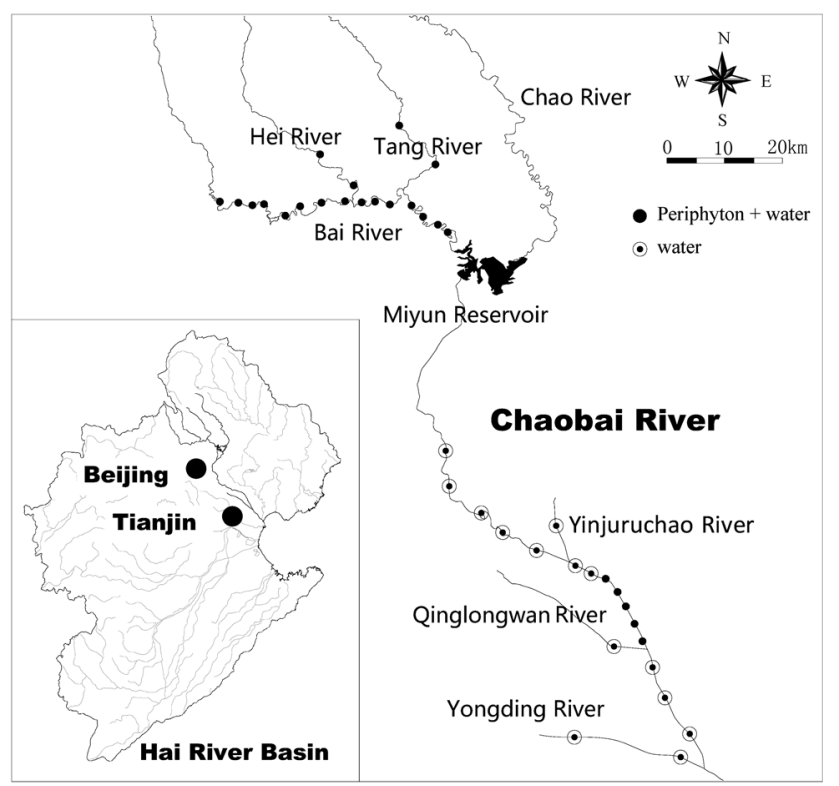

Figure 1. Map showing the sampling stations in the Chaobai River Watershed, northern China.
Chaobai rivers and their tributaries (the Hei, Tang, Qinglongwan, and Yongding rivers) as our main study sites in the CRW, because the water quality in these systems covered a range of trophic classes (oligotrophic, mesotrophic, eutrophic, and hypereutrophic), which facilitated our study of periphyton responses. Water and periphyton samples were collected monthly at 38 study sites from April to June 2010.

\subsection{Water sampling and analysis}

After collected by a water sampler (UWITEC-WSC, Austria) in the proximity of the bottom, water samples (three replicates) $(50 \mathrm{~mL})$ were acidified to $\mathrm{pH}<2$, and then analyzed in the laboratory within $72 \mathrm{~h}$. Samples for dissolved nutrient analyses (nitrite nitrogen, $\mathrm{NO}_{2}{ }^{-} \mathrm{N}$; nitrate nitrogen, $\mathrm{NO}_{3}{ }^{-} \mathrm{N}$; and ammonium nitrogen, $\mathrm{NH}_{4}{ }^{+}-\mathrm{N}$ ) were filtered in the field through a $0.45 \mu \mathrm{m}$ cellulose acetate membrane (Whatman), while samples for total $\mathrm{N}(\mathrm{TN})$ and total $\mathrm{P}(\mathrm{TP})$ were unfiltered. In the laboratory, samples were digested with alkaline persulfate before TN analysis and with persulfate before TP analysis. An automated chemistry analyzer (Smart Chem 200) was used to determine the $\mathrm{NO}_{2}{ }^{-} \mathrm{N}^{-} \mathrm{NO}_{3}{ }^{-} \mathrm{N}, \mathrm{NH}_{4}{ }^{+}-\mathrm{N}$, and TN concentrations, using a detection limit of $0.001 \mathrm{mg} / \mathrm{L}$. TP was analyzed by inductively coupled plasma-mass spectrometry (7500a, Agilent, USA) (detection limit $0.001 \mu \mathrm{g} / \mathrm{L}$ ).

\subsection{Periphyton sampling, element analysis, and classification}

Field investigations in the HRB showed major differences in the periphyton community structure, from small epilithic/epiphytic diatoms to large filamentous algae. Sampling sites with similar conditions (e.g., light (without shade), substrata (hard), water depth $(0.5-1.0 \mathrm{~m})$ and flow velocity $(1-2 \mathrm{~m} / \mathrm{s}))$ were selected to avoid physical and hydrological disturbances. Attached diatoms were collected from rock surfaces using a nylon-bristled brush, while filamentous algae were directly collected from river bottom using a knife. At least three samples were collected at each study site each month, unless there was no periphyton present. Each sample was further divided into three parts for analysis. The first part was preserved in 3-5\% glutaraldehyde solution [22] at the sampling site and the community structure was identified by microscopy (Olympus BX51) upon arrival in the laboratory. The second part was stored at $-16^{\circ} \mathrm{C}$ in a cooler (Mobicool) and then freeze dried on arrival at the laboratory. After drying, the samples were ground so that periphyton particles could pass through a 100-mesh sieve prior to analysis. The $\mathrm{P}$ content was determined by inductively coupled plasma optical emission spectrometry (OPTIMA 2000DV, Perkin Elmer, USA) after microwave digestion (CEM, Matthews, NC, USA). An element analyzer (Vario EL III) was used to analyze the carbon $(C)$ and N contents [23]. Spirulina (GBW10025, National Institute of Metrology, China) was used as an external standard for elemental analysis. The third part of the sample was retained as a backup in case of any analysis failure.

Algae are a major periphyton group and their structure can differ greatly (from unicellular diatoms to filamentous algae). Previous studies have offered many methods of periphyton classification. For example, Maltalis and Vincent divided periphyton by color and other characteristics into black crust, brown film, green crust and green filamentous [24]. Others have categorized periphyton by thickness [25], lake depth gradient [26], and the degree of 
attachment [27]. The method is generally selected based on the research question. In this study, typology classification of periphyton can facilitate identification of pollution factors that affect periphyton stoichiometry and can help estimate field water quality [28].

\subsection{Data analysis}

Statistical analyses were conducted using PASW Statistics 18 for Windows. We used binary logistic regression to predict the priority pollutants that influenced the periphyton distribution. We examined the relationships between water nutrients and periphyton elements with bivariate correlation analysis (two-tailed Spearman). Origin Pro 8.0 was used to plot the experimental data.

\section{Results}

\subsection{Water quality ( $\mathrm{N}$ and $\mathrm{P}$ ) and periphyton distribution}

The $\mathrm{N}$ and $\mathrm{P}$ concentrations in the CRW studied rivers are shown in Supporting Information Table S1. Concentrations varied widely throughout the CRW: TN concentrations ranged from 0.57 to $46.32 \mathrm{mg} / \mathrm{L}$, while TP concentrations ranged from not detected to $6.28 \mathrm{mg} / \mathrm{L}$. The average TN concentration increased from 3.69 to $7.39 \mathrm{mg} / \mathrm{L}$, while the average TP concentration increased from 0.01 to $0.43 \mathrm{mg} / \mathrm{L}$, from upstream (the Bai River and its tributaries) to downstream (the Chaobai River and its tributaries). $\mathrm{NH}_{4}{ }^{+}-\mathrm{N}$ concentrations showed a significant increasing trend with distance downstream, and increased from 0.06 to $3.44 \mathrm{mg} / \mathrm{L}$, accounting for between 1.62 and $46.55 \%$ of TN, respectively. The results indicated that trophic state differed from upstream to downstream in the CRW.

In this study, we observed differently structured periphyton, ranging from the crust forming stage to the filamentous stage, along the direction of river flow. Thus, we divided the periphyton into three different types based on their typologies as follows (Fig. 2): attached diatoms $(\mathrm{AD})$, filamentous algae $(\mathrm{FA})$, and filamentous algae with epiphyte (FE). $\mathrm{AD}$ was primarily composed of epilithic unicellular diatoms (Supporting Information Table S2), such as Fragilaria and Cymbella. FA represents periphyton communities composed of filamentous algae with few (biomass $<5 \%$ ) or no

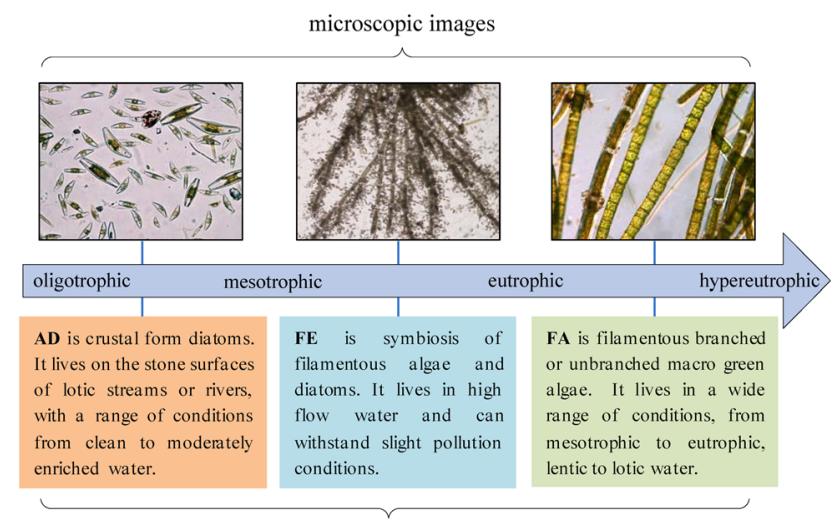

habitat \& distribution

Figure 2. Examples of periphyton classified by their typologies. unicellular diatoms (e.g., Cladophora, Oscillatoria, and Spirogyra). FE represents filamentous algae in symbiosis with epiphytic diatoms that serve as a hybrid type. Cladophora with Tabellaria attached was a typical common FE species.

\subsection{Relationship between periphyton and water quality}

In the rivers of the CRW, water with periphyton had lower TN and TP concentrations than water without periphyton (Tab. 1). The nitrogen speciation also differed between the water with and without periphyton. In particular, $\mathrm{NH}_{4}{ }^{+}-\mathrm{N}$ accounted for, on average, $40.90 \%$ of TN in non-periphyton water, while it accounted for only $2 \%$ in periphyton water. Mean values show that $\mathrm{NH}_{4}{ }^{+}-\mathrm{N}$ and TP had major influence on periphyton distribution. Statistical analysis using binary logistic regression suggests that the influence of $\mathrm{NH}_{4}{ }^{+}-\mathrm{N}$ was stronger than that of TP (correct class $=67.1 \%, \chi^{2}=50.33, p<0.001$ ). For this study, the threshold concentration for periphyton existence (i.e., the maximum $\mathrm{NH}_{4}^{+}-\mathrm{N}$ concentration in water containing periphyton) was $2.56 \mathrm{mg} / \mathrm{L}$. Moreover, $\mathrm{N}$ and $\mathrm{P}$ concentrations in water containing $\mathrm{FE}$ were a little higher than those containing $\mathrm{AD}$, while nutrient concentrations (in particular $\mathrm{NH}_{4}{ }^{+} \mathrm{N}$ and $\mathrm{TP}$ ) increased sharply in water containing FA (Tab. 1).

\subsection{Periphyton ecological stoichiometry (C, N, and P)}

The $\mathrm{C}$ contents of different periphyton types were ranked as follows: FE $(19.78 \pm 9.88 \mathrm{mmol} / \mathrm{g})>\mathrm{AD}(17.43 \pm 12.66 \mathrm{mmol} / \mathrm{g})>\mathrm{FA}(16.15 \pm$ $6.49 \mathrm{mmol} / \mathrm{g})$. $\mathrm{N}$ contents were as follows: $\mathrm{FE}(1.55 \pm 0.81 \mathrm{mmol} / \mathrm{g})>\mathrm{FA}$ $(1.45 \pm 0.89 \mathrm{mmol} / \mathrm{g})>\mathrm{AD}(1.15 \pm 0.92 \mathrm{mmol} / \mathrm{g})$, and $\mathrm{P}$ contents were ranked in the order $\mathrm{FA}(0.07 \pm 0.04 \mathrm{mmol} / \mathrm{g})>\mathrm{FE}(0.06 \pm 0.03 \mathrm{mmol} / \mathrm{g})$ $>\mathrm{AD}(0.02 \pm 0.01 \mathrm{mmol} / \mathrm{g})$. Scatterplots of $\mathrm{C}$ and $\mathrm{N}(\mathrm{N}$ and $\mathrm{P})$, total periphyton and the three types of periphyton were produced and linearly fitted (the intercepts were forced through zero) (Fig. 3). The total $\mathrm{C} / \mathrm{N}$ ratio was $12(\mathrm{~N} / \mathrm{P}=23)$, which is higher than the Redfield ratio $(\mathrm{C} / \mathrm{N} / \mathrm{P}=106: 16: 1)[29]$. The ratios for the three different groups were ranked as follows: $\mathrm{AD}(\mathrm{C} / \mathrm{N}=14)>\mathrm{FE}(\mathrm{C} / \mathrm{N}=12)>\mathrm{FA}(\mathrm{C} / \mathrm{N}=10)$, $\mathrm{AD}(\mathrm{N} / \mathrm{P}=47)>\mathrm{FE}(\mathrm{N} / \mathrm{P}=24)>\mathrm{FA}(\mathrm{N} / \mathrm{P}=19)$.

\section{Discussion}

\subsection{Shifts in periphyton assemblages}

The change in periphyton type from $\mathrm{AD}$ to $\mathrm{FE}$ to FA suggests two shifts in periphyton assemblages (AD to FE and FE to FA), which should be examined (Fig. 2). AD represented clean ambient water, FE indicated slight pollution, and FA showed $\mathrm{N}$ contamination (Tab. 1). Therefore, these two shifts represent the change from unicellular diatoms (clean water) to filamentous algae (polluted water). A key feature in the shift from $\mathrm{AD}$ to $\mathrm{FE}$ was the appearance of filamentous algae in periphyton assemblages. Diatoms disappeared from FE to FA in response to pollution stress (Supporting Information Table S2). The EPA benthic algae model value for $\mathrm{NH}_{4}{ }^{+} \mathrm{N}$ preference is $0.025 \mathrm{mg} / \mathrm{L}$ [30]. Other studies have also shown that $\mathrm{NH}_{4}{ }^{+} \mathrm{N}$ concentrations $>0.028 \mathrm{mg} / \mathrm{L}$ inhibit phytoplankton photosynthesis and growth [31]. As levels of $\mathrm{NH}_{4}{ }^{+}-\mathrm{N}$ increase, epiphyte diatoms in FE may perish, however, filamentous algae have relatively strong tolerances to $\mathrm{NH}_{4}{ }^{+} \mathrm{N}$. We observed that there were no periphyton when $\mathrm{NH}_{4}{ }^{+} \mathrm{N}$ concentrations were $>2.56 \mathrm{mg} / \mathrm{L}$ in the studied rivers, 
Table 1. Nutrient concentrations in water with and without periphyton (mean $\pm \mathrm{SD})(\mathrm{mg} / \mathrm{L})$

\begin{tabular}{|c|c|c|c|c|c|}
\hline Periphyton & Type & $\mathrm{TN}$ & $\mathrm{NO}_{\mathrm{x}}{ }^{-}-\mathrm{N}$ & $\mathrm{NH}_{4}{ }^{+}-\mathrm{N}$ & $\mathrm{TP}$ \\
\hline No & - & $6.48 \pm 6.02$ & $2.05 \pm 1.66$ & $2.65 \pm 4.66$ & $0.31 \pm 0.74$ \\
\hline \multirow[t]{4}{*}{ Yes } & All types & $3.91 \pm 2.64$ & $1.97 \pm 1.35$ & $0.22 \pm 0.52$ & $0.05 \pm 0.19$ \\
\hline & $\mathrm{AD}$ & $3.00 \pm 2.40$ & $1.27 \pm 0.79$ & $0.06 \pm 0.06$ & ND \\
\hline & $\mathrm{FE}$ & $3.26 \pm 2.92$ & $1.70 \pm 1.18$ & $0.06 \pm 0.09$ & $0.01 \pm 0.01$ \\
\hline & FA & $5.18 \pm 1.75$ & $2.64 \pm 1.50$ & $0.50 \pm 0.80$ & $0.12 \pm 0.30$ \\
\hline
\end{tabular}

ND, not detected.

suggesting that $\mathrm{NH}_{4}{ }^{+} \mathrm{N}$ may be the main influence on periphyton distribution and assemblage shifts.

\subsection{Effects of water pollution on periphyton elemental composition}

The $\mathrm{C}, \mathrm{N}$, and $\mathrm{P}$ contents of both unicellular diatoms and filamentous algae can vary according to the ambient water quality. The mechanism that controls the elemental composition for the three periphyton types can be explained from the molecular composition of cells. Some cellular components, such as nucleic acids and energetic nucleotides, are composed of $\mathrm{C}, \mathrm{N}$ and $\mathrm{P}$, but others (carbohydrates and chlorophyll) contain only $\mathrm{C}$ and $\mathrm{N}$ without $\mathrm{P}$ [18]. In the CRW studied rivers, FE contained high levels of $\mathrm{C}$ and $\mathrm{N}$ when compared with $\mathrm{AD}$ and $\mathrm{FA}$, which may be due to the coexistence of epiphytic diatoms and filamentous algae in FE.

Based on the fact that $\mathrm{N}$ does not exist independently in all cellular components but rather is generally combined with either $C$ or $\mathrm{P}$, and on the results of this study, we can conclude that either $\mathrm{C}$ and $\mathrm{N}$ or $\mathrm{N}$ and $\mathrm{P}$ are strongly correlated. There was a weak correlation between $\mathrm{C}$ and $\mathrm{P}(r=0.388, p<0.001)$, especially for $\mathrm{FE}$ $(r=0.317, p<0.001)$, while both $\mathrm{C}$ and $\mathrm{N}(r=0.839, p<0.001)$ and $\mathrm{N}$ and $\mathrm{P}(r=0.641, p<0.001)$ were strongly correlated (Tab. 2$)$. These results suggest that the $\mathrm{C} / \mathrm{N}$ and $\mathrm{N} / \mathrm{P}$ ratios may be good indicators for measuring periphyton response to water pollution when using ES [32]. In fact, when compared with $\mathrm{C} / \mathrm{N}, \mathrm{N} / \mathrm{P}$ may be a good indicator for monitoring and predicting combined pollution
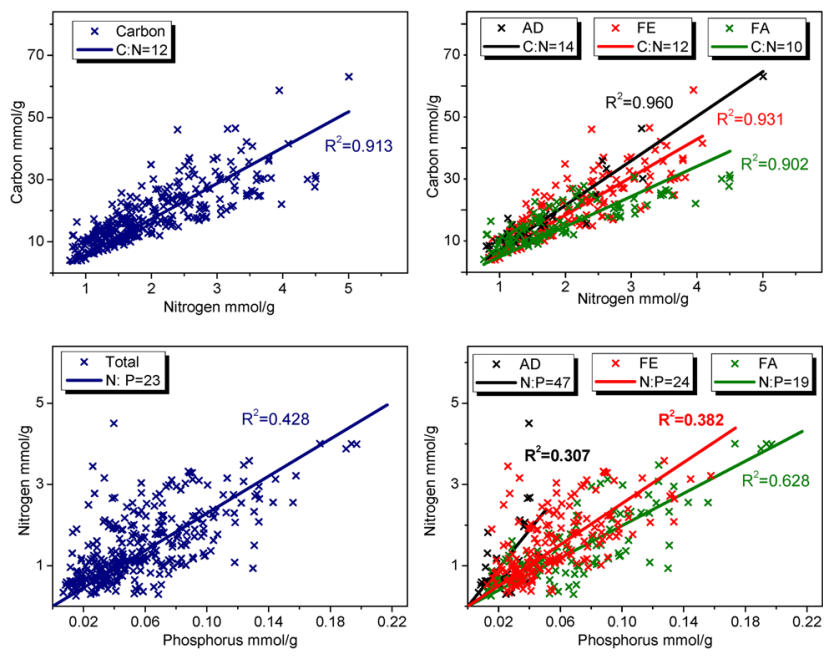

Figure 3. Periphyon stoichiometry $(\mathrm{C} / \mathrm{N}$ and $\mathrm{N} / \mathrm{P})$ of total periphyton and the three types. directly, as the $\mathrm{N}$ and $\mathrm{P}$ in the periphyton came from the water. Element stoichiometric ratios of freshwater algae differed among pelagic plankton. Other researchers found that the optimal $\mathrm{C} / \mathrm{N} / \mathrm{P}$ ratio for the maximum benthic microalgal growth rate was 119:17:1 and that $\mathrm{N} / \mathrm{P}>22$ indicated P-limitation [33]. In the present study, the $\mathrm{C} / \mathrm{N}$ and $\mathrm{N} / \mathrm{P}$ ratios among the three types represented different pollution states, which are reflected by the differences in ratios.

The $\mathrm{C} / \mathrm{N}$ ratio in periphyton gradually approached the Redfield ratio from $\mathrm{AD}$ to $\mathrm{FE}$ to $\mathrm{FA}$ (Fig. 3). The coefficients of determination $\left(R^{2}\right)$ for all types were $>0.9$, indicating that the $\mathrm{C} / \mathrm{N}$ ratios of the three periphyton types were remarkably stable and demonstrated homeostasis. Although this study did not reveal which factor caused the $\mathrm{C} / \mathrm{N}$ ratios of the three types to be greater than those found by Hillebrand and Sommer [34], the results showed that the $\mathrm{C} / \mathrm{N}$ ratios for diatoms and filamentous algae were obviously very different, suggesting different effects of pollution on higher trophic levels.

The $R^{2}$ value of $\mathrm{N} / \mathrm{P}$ in $\mathrm{AD}$ and $\mathrm{FE}$ were very low $\left(R^{2}<0.4\right)$, which suggests that they varied greatly and were susceptible to water pollution. Compared with the $\mathrm{C} / \mathrm{N}$ ratio, which was primarily determined by $\mathrm{N}$, variations in the $\mathrm{N} / \mathrm{P}$ ratio can indicate both $\mathrm{N}$ and $\mathrm{P}$ pollution. The $\mathrm{N} / \mathrm{P}$ ratios varied for the different groups, for example, $\mathrm{AD}$ had an N/P ratio of $47, \mathrm{FE}$ had an N/P ratio of 24 , while FA had an N/P ratio of 19 (Fig. 3). Correlation analysis suggested that the differences in the ratios for the three groups reflect the effects of different pollutants. For example, $\mathrm{AD}$ was influenced by $\mathrm{NH}_{4}{ }^{+}-\mathrm{N}$ and $\mathrm{TP}$, while FE was influenced by $\mathrm{NO}_{\mathrm{x}}{ }^{-} \mathrm{N}\left(\mathrm{NO}_{2}{ }^{-} \mathrm{-N}\right.$ and $\left.\mathrm{NO}_{3}{ }^{-} \mathrm{-N}\right)$ and FA was influenced by TP (Tab. 2). Terry found that the N/P ratio increased for low growth rates, and decreased for high growth rates of Pavlova lutheri [34]. For this study, the negative correlations between the N/P ratios for the three types and the concentrations of water pollutants indicate that the algal growth rates increased with the latter. However, other researchers have suggested that there are no simple rules to predict how the $\mathrm{N} / \mathrm{P}$ ratio will change [35]. The results of the present study suggest that changes in the N/P ratio are related to organism typologies, despite the complex community structure.

Variations in the elemental composition of periphyton may be attributable to (1) non-homeostatic effects of periphyton; (2) changes in the periphyton community structure, or (3) a combination of both (1) and (2). Apparently, an algal species cannot adapt to any arbitrary $\mathrm{N} / \mathrm{P}$ pollution levels. Therefore, a high imbalance of $\mathrm{N}$ and $\mathrm{P}$ may cause shifts in periphyton assemblages. However, Grover found that increasing the $\mathrm{N} / \mathrm{P}$ supply ratio to phytoplankton resulted in reduced diversity because only certain species were able to absorb $\mathrm{P}$ and finally dominated the community [36]. Periphyton communities may exhibit changes similar to those observed in the phytoplankton. This investigation showed that periphyton responded to water 
Table 2. Spearman correlation analyses of periphyton $C, N$ and $P$

\begin{tabular}{|c|c|c|c|c|c|c|c|}
\hline & \multirow[b]{2}{*}{ Type } & \multicolumn{2}{|c|}{$\mathrm{N}$} & \multicolumn{2}{|c|}{$\mathrm{C}$} & \multicolumn{2}{|c|}{$\mathrm{N} / \mathrm{P}$} \\
\hline & & $r$ & $p$ & $r$ & $p$ & $r$ & $p$ \\
\hline \multirow[t]{4}{*}{$P$} & $\mathrm{AD}$ & $0.571^{* * *}$ & 0.001 & $0.531^{* * *}$ & 0.003 & -0.218 & 0.247 \\
\hline & $\mathrm{FE}$ & $0.630^{* *}$ & 0.000 & $0.317^{* * *}$ & 0.000 & $-0.305^{* *}$ & 0.000 \\
\hline & FA & $0.718^{* * *}$ & 0.000 & $0.500^{* * *}$ & 0.000 & $-0.470^{* *}$ & 0.000 \\
\hline & Total & $0.641^{* *}$ & 0.000 & $0.388^{* *}$ & 0.000 & $-0.461^{* *}$ & 0.000 \\
\hline \multirow[t]{4}{*}{$\mathrm{N}$} & $\mathrm{AD}$ & 1 & & $0.839^{* *}$ & 0.000 & $0.592^{* * *}$ & 0.001 \\
\hline & $\mathrm{FE}$ & 1 & & $0.854^{* * *}$ & 0.000 & $0.482^{* * *}$ & 0.000 \\
\hline & FA & 1 & & $0.824^{* * *}$ & 0.000 & 0.204 & 0.032 \\
\hline & Total & 1 & & $0.848^{* * *}$ & 0.000 & $0.322^{* * *}$ & 0.000 \\
\hline \multirow[t]{4}{*}{$\mathrm{C} / \mathrm{N}$} & $\mathrm{AD}$ & $-0.729^{* *}$ & 0.000 & -0.328 & 0.077 & & \\
\hline & $\mathrm{FE}$ & $-0.338^{* *}$ & 0.000 & 0.169 & 0.027 & & \\
\hline & FA & $-0.703^{* *}$ & 0.000 & -0.217 & 0.023 & & \\
\hline & Total & $-0.506^{* *}$ & 0.000 & -0.002 & 0.974 & & \\
\hline
\end{tabular}

${ }^{* *}$ Correlation is significant at the 0.01 level (2-tailed).

pollution (especially $\mathrm{N}$ pollution) by approach (3). Overall, these findings indicate that we can identify pollutants based on the periphyton type, and we can use this method to evaluate water quality in the future.

\subsection{Using the ES method to indicate ecological risks from $\mathrm{NH}_{4}{ }^{+}-\mathrm{N}$ pollution in the HRB}

High $\mathrm{NH}_{4}^{+}-\mathrm{N}$ concentrations may inhibit benthic production, and even low levels can be reflected by shifts in the periphyton assemblages. $\mathrm{NH}_{4}{ }^{+}-\mathrm{N}$ pollution, as observed in the HRB, is a serious environmental issue in China. Historical data supplied by the HRB Water Resources Protection Bureau show that the rivers are seriously polluted by $\mathrm{NH}_{4}{ }^{+}-\mathrm{N}$ (Supporting Information Fig. S1). Indeed, $\mathrm{NH}_{4}{ }^{+}-\mathrm{N}$ concentrations in most sub-basins were higher than the tolerance threshold of $2.56 \mathrm{mg} / \mathrm{L}$ established by this study. We employed the ES method to highlight the effects of $\mathrm{N}$ pollution on periphyton distribution, elemental composition, and shifts in periphyton assemblages in the rivers of HRB, and found that $\mathrm{NH}_{4}{ }^{+} \mathrm{N}$ was the key influence on periphyton distribution and assemblage shifts. The findings from this study clearly demonstrate that $\mathrm{NH}_{4}{ }^{+} \mathrm{N}$ pollution control is necessary and it should be given priority when developing freshwater management strategies in the HRB.

\section{Conclusions}

Using typologies, we classified periphyton in the HRB into AD, FA, and $\mathrm{FE}$. $\mathrm{AD}$ represented clean ambient water, $\mathrm{FE}$ indicated slight pollution, while FA indicated water that had been contaminated by $\mathrm{N}$. $\mathrm{NH}_{4}{ }^{+}-\mathrm{N}$ was the main influence on periphyton distribution and assemblage shifts. In addition, the $\mathrm{N} / \mathrm{P}$ ratio in $\mathrm{AD}$ was mainly influenced by $\mathrm{NH}_{4}{ }^{+} \mathrm{N}$ and TP, while in FE it was mainly affected by $\mathrm{NO}_{\mathrm{x}}{ }^{-} \mathrm{N}$ and in FA it was mainly influenced by TP. There were two main factors contributing to variations in periphyton elemental composition in this study: non-homeostatic effects of periphyton and changes in the periphyton community structure. This study showed how periphyton responds to water pollution (especially $\mathrm{N}$ pollution). The findings indicate that the pollution status can be directly reflected by periphyton types and this method will be useful to evaluate water quality in future.

\section{Acknowledgments}

This research was supported by the National Natural Science Foundation of China (No. 21107126), the National Water Pollution Control Program (No. 2012ZX07203-006), and the One-Three-Five Program of the Research Center for Eco-Environmental Sciences (No. YSW2013B02).

The authors have declared no conflict of interest.

\section{References}

[1] J. Edmondson, E. Terribile, J. A. Carroll, E. A. C. Price, S. J. M. Caporn, The Legacy of Nitrogen Pollution in Heather Moorlands: Ecosystem Response to Simulated Decline in Nitrogen Deposition over Seven Years, Sci. Total Environ. 2013, 444, 138-144.

[2] S. S. Kaushal, P. M. Groffman, L. E. Band, E. M. Elliott, C. A. Shields, C. Kendall, Tracking Nonpoint Source Nitrogen Pollution in Human-Impacted Watersheds, Environ. Sci. Technol. 2011, 45, 8225-8232.

[3] M. Onderka, S. Wrede, M. Rodný, L. Pfister, L. Hoffmann, A. Krein, Hydrogeologic and Landscape Controls of Dissolved Inorganic Nitrogen (DIN) and Dissolved Silica (DSi) Fluxes in Heterogeneous Catchments, J. Hydrol. 2012, 450, 36-47.

[4] J. C. Cornwell, W. M. Kemp, Sediment Flux Modeling: Simulating Nitrogen, Phosphorus, and Silica Cycles, Estuaries Coastal Shelf Sci. 2013, 131, 245-263.

[5] M. J. Bowes, N. L. Ings, S. J. McCall, A. Warwick, C. Barrett, H. D. Wickham, S. A. Harman, et al., Nutrient and Light Limitation of Periphyton in the River Thames: Implications for Catchment Management, Sci. Total Environ. 2012, 434, 201-212.

[6] R. W. Sterner, Daphnia Growth on Varying Quality of Scenedesmus: Mineral Limitation of Zooplankton, Ecology 1993, 74, 2351-2360.

[7] M. T. Barbour, J. Gerritsen, B. Snyder, J. Stribling (Eds.), Rapid Bioassessment Protocols for Use in Streams and Wadeable Rivers, US EPA, Washington, DC 1999.

[8] F. R. Hauer, G. A. Lamberti (Eds.), Methods in Stream Ecology, Academic Press, San Diego 2011.

[9] J. R. D. Guimaraes, J. B. N. Mauro, M. Meili, M. Sundbom, A. L. Haglund, S. A. Coelho-Souza, L. D. Hylander, Simultaneous Radioassays of Bacterial Production and Mercury Methylation in the Periphyton of a Tropical and a Temperate Wetland, J. Environ. Manage. 2006, 81, 95-100.

[10] P. V. McCormick, J. Cairns, Jr., Algae as Indicators of Environmental Change, J. Appl. Phycol. 1994, 6, 509-526. 
[11] R. J. Stevenson, M. L. Bothwell, R. L. Lowe, J. H. Thorp (Eds.), Algal Ecology: Freshwater Benthic Ecosystem, Academic Press, San Diego 1996.

[12] C. Vis, C. Hudon, A. Cattaneo, B. Pinel-Alloul, Periphyton as an Indicator of Water Quality in the St Lawrence River (Quebec, Canada), Environ. Pollut. 1998, 101, 13-24.

[13] E. Gaiser, Periphyton as an Indicator of Restoration in the Florida Everglades, Ecol. Indic. 2009, -S45.

[14] P. C. Frost, R. S. Stelzer, G. A. Lamberti, J. J. Elser, Ecological Stoichiometry of Trophic Interactions in the Benthos: Understanding the Role of C/N/P Ratios in Lentic and Lotic Habitats, J. N. Am. Benthol. Soc. 2002, 515-528.

[15] G. S. Kolb, C. Palmborg, P. A. Hamback, Ecological Stoichiometry and Density Responses of Plant-Arthropod Communities on Cormorant Nesting Islands, PLoS One 2013, 8, e61772.

[16] T. Saeed, G. Z. Sun, A Review on Nitrogen and Organics Removal Mechanisms in Subsurface Flow Constructed Wetlands: Dependency on Environmental Parameters, Operating Conditions and Supporting Media, J. Environ. Manage. 2012, 112, 429-448.

[17] R. W. Sterner, J. J. Elser (Eds.), Ecological Stoichiometry: The Biology of Elements from Molecules to the Biosphere, Princeton University Press, Princeton, NJ 2002.

[18] C. Bradshaw, U. Kautsky, L. Kumblad, Ecological Stoichiometry and Multi-Element Transfer in a Coastal Ecosystem, Ecosystems 2012, 15 (4), 591-603.

[19] G. Y. Rhee, Effects of N/P Atomic Ratios and Nitrate Limitation on Algal Growth, Cell Composition, and Nitrate Uptake, Limnol. Oceanogr. 1978, 23, 10-25.

[20] R. S. Stelzer, G. A. Lamberti, Effects of N/P Ratio and Total Nutrient Concentration on Stream Periphyton Community Structure, Biomass, and Elemental Composition, Limnol. Oceanogr. 2001, 46, 356-367.

[21] P. C. Frost, W. F. Cross, J. P. Benstead, Ecological Stoichiometry in Freshwater Benthic Ecosystems: An Introduction, Freshwater Biol. 2005, 50, 1781-1785.

[22] B. Biggs, C. Kilroy (Eds.), Stream Periphyton Monitoring Manual, National Institute of Water and Atmospheric Research, Christchurch, New Zealnd 2000.
[23] A. Quigg, Z. V. Finkel, A. J. Irwin, Y. Rosenthal, T. Y. Ho, J. R. Reinfelder, O. Schofield, et al., The Evolutionary Inheritance of Elemental Stoichiometry in Marine Phytoplankton, Nature 2003, 425, 291-294.

[24] M. J. Maltais, W. F. Vincent, Periphyton Community Structure and Dynamics in a Subarctic Lake, Can. J. Bot. 1997, 75, 1556-1569.

[25] A. Quesada, W. F. Vincent, D. R. Lean, Community and Pigment Structure of Arctic Cyanobacterial Assemblages: The Occurrence and Distribution of UV-Absorbing Compounds, FEMS Microbiol. Ecol. 1999, 28, 315-323.

[26] K. Sabbe, D. A. Hodgson, E. Verleyen, A. Taton, A. Wilmotte, K. Vanhoutte, W. Vyverman, Salinity, Depth and the Structure and Composition of Microbial Mats in Continental Antarctic Lakes, Freshwater Biol. 2004, 49, 296-319.

[27] J. Kalff (Ed.), Limnology: Inland Water Ecosystems, Prentice Hall, Upper Saddle River, NJ 2002.

[28] W. Z. Tang, J. G. Cui, B. Q. Shan, C. Wang, W. Q. Zhang, Heavy Metal Accumulation by Periphyton Is Related to Eutrophication in the Hai River Basin, Northern China, PLoS One 2014, 9, e86458.

[29] A. C. Redfield, The Biological Control of Chemical Factors in the Environment, Am. Sci. 1958, 46, 205-221.

[30] R. B. Ambrose, J. L. Martin, T. A. Wool (Eds.), Benthic Algae-Model Theory and User's Guide, US EPA, Washington, DC 2006.

[31] A. Abeliovich, Y. Azov, Toxicity of Ammonia to Algae in Sewage Oxidation Ponds, Appl. Environ. Microb. 1976, 31, 801-806.

[32] P. M. Glibert, Ecological Stoichiometry and Its Implications for Aquatic Ecosystem Sustainability, Curr. Opin. Environ. Sustainability 2012, 4, 272-277.

[33] H. Hillebrand, U. Sommer, The Nutrient Stoichiometry of Benthic Microalgal Growth: Redfield Proportions Are Optimal, Limnol. Oceanogr. 1999, 44, 440-446.

[34] K. L. Terry, Nitrogen and Phosphorus Requirements of Pavlova lutheri in Continuous Culture, Bot. Mar. 1980, 23, 757-764.

[35] G. I. Ågren, The C/N/P Stoichiometry of Autotrophs - Theory and Observations, Ecol. Lett. 2004, 7, 185-191.

[36] J. P. Grover (Ed.), Resource Competition, Springer, London 1997. 